\title{
SISTEM PENERANGAN SELASAR RUMAH SAKIT BERBANTUAN PENGINDRAAN INFRA MERAH BERBASIS ECOGREEN
}

\author{
Frisa Yugi Hermawan, Puji Rachmanto \\ Politeknik Kesehatan Jakarta II \\ Email: frisayugihermawan@gmail.com
}

\begin{abstract}
This intelligent system is made as the application of teaching materials in lighting system for Hospital hallway. Hospital as a public health facilities is commonly visited by people thus it must have a lighting system to make people feel save and comfort. The purpose of this research is to test the intelligent system modeling module by integrating series of parallelseries lamps and infrared sensors as a single moving object detector. The research employ series of activity from literature review process of various sources, designing the integrastion system, programing, component test, and testing the whole function of program and tool. The progran was conducted by arranging three groups of lights with different lit order, referring to four Infra Red sensors. Each light poweredfixed power valueusingnamely 25 Watt in parallel circuit and the power used changed into 10 Watt when in the series. The bounce state is found when the lamp circuit is connected to a voltage source. The results of this study indicate that the regulation of ligth power value by intelligent system, which is illuminated in parallel circuit is 25 Watt, can be decreased to 10 Watt in series circuit. Decrease of light power by $60 \%$ either per ligth or in group of ligth can be controlled by intelligent system without reducing the comfort of lighting the hallway.
\end{abstract}

Keywords: intelligent system, Hospital hallway, ecogreen system

\section{ABSTRAK}

Sistem cerdas ini dibuat sebagai penerapan bahan ajar pada system penerangan selasar Rumah Sakit.Rumah Sakitmerupakan salah satu fasilitas umum dan dikunjungi oleh orangorang yang harus memiliki sistem pencahayaan dapat membuat orang-orang di Rumah Sakit merasa nyaman.Tujuan penelitian ini yakni melakukan uji coba modul pemodelan system cerdas dengan mengintegrasikan rangkaian lampu seri-parallel dan sensor infra merah sebagai pendeteksi objek bergerak tunggal.Tahapan penelitian dimulai daristudi literatur dari berbagai sumber, perancangan sistem, perancangan program, uji fungsi program dan komponen, hingga uji fungsi keseluruhan.Penelitian dilakukan dengan mengatur tiga buah kelompok lampu dengan urutan menyala yang berbeda, mengacu pada empat buah sensor Infra Merah.Masing-masing daya lampu yang digunakan adalah 25 Watt, dengan nilai daya yang tetap disaat dalam rangkaian parallel serta nilai lampu tersebut akan menjadi 10 Watt disaat dalam rangkaian seri. Keadaan bouncing ditemukan ketika rangkaian lampu dihubungkan ke sumber tegangan.Hasil penelitian ini menunjukan bahwa pengaturan nilai daya lampu oleh system cerdas, yang menyala dalam rangkaian parallel adalah 25 Watt, dapat diturunkan menjadi 10 Watt dalam rangkaian seri. Penurunan daya lampu sebesar 60\%baik per lampu maupun dalam kelompok lampu dapat dikontrol dengan system cerdas tanpa mengurangi kenyamanan penerangan selasar.

Kata kunci: system cerdas, selasar Rumah Sakit, sistem ecogreen 


\section{PENDAHULUAN}

Bahan ajar adalah hal mutlak yang harus ada di setiap perkuliahan. Bahan ajar juga merupakan salah satu dari sumber belajar(Malalina \& Kesumawati 2013)(Yosi Abdian Tindaon 2012). Salah satu sumber bahan ajar dapat diciptakan sendiri oleh seorang dosen.Bahan ajar bukan hanya sebatas penyesuaian kebutuhan belajar namun juga harus dapat menyesuaikan dengan kondisi perkembangan teknologi dan kebutuhan lingkungan sekitar.Salah satu penerapan dari perkembangan bahan ajar adalah berupa system cerdas.Sistem cerdas merupakan salah satu dari aplikasi teknologi.Sistem cerdas yang merupakan bentuk dari aplikasi bahan ajar adalah sistem cerdas yang mengatur kondisi tata pencahayaan otomatis pada selasar rumah sakit.

Sistem penerangan pada selasar rumah sakit adalah bagian yang tak terpisahkan sebagai bagian yang turut memberikan kenyamanan kepada semua orang di lingkungan rumah sakit. Sistem penerangan adalah bagian dari kebutuhan yang memiliki peranan yang cukup besar mengkonsumsi beban daya listrik(Mineral 2012). Atas kondisi tersebut diperlukan efisiensi demi menekan beban daya penggunaan energy listrik salah hsatunya menggunakan system cerdas.Standart pencahayaan malam hari untuk selasar / koridor Rumah Sakit masuk ke dalam kategori pencahayaan "B". Kategori tersebut memiliki standart Lux Pencahayaan 50-75-100(Departemen Kesehatan RI 1992)(Departemen Kesehatan RI 2004). Sistem cerdas ini menerapkan pola rangkaian SeriParalel.Lampu yang digunakan di rangkaian dihubungkan dengan pola seriparalel secara sekaligus, sehingga bila kita ingin mengubah kondisi lampu dari keadaan terang ke redup, maka rangkaian juga berubah dari kondisi paralel ke seri (Gunadarma n.d.).Kategori tersebut telah masuk ke dalam kategori lingkungan cerdas. Lingkungan cerdas (Intelligent environments (IEs))adalah system lingkungan yang luas yang menyediakan informasi dan layanan kepada merekapengguna(Park et al. 2015). Sistem ini berupa prototipe sebagai penerapan dari berbagai materi perkuliahan yang pastinya dapat berfungsi sebagai modul aplikatif kolaborasi.Porsi kolaborasinya nampak pada mata kuliah Instalasi Listrik dan Teknik Tenaga Listrik pada rangkaian installasi lampu Seri-Paralel.Mata kuliah Mikrokontroller pada bagian pemrograman dan pengaturan (controlling) system.Mata kuliah Sensor dan Transducer pada pemilahan jenis sensor yang digunakan.

Untuk mengontrol pola seri-paralel tersebut diperlukan system cerdas sebuah Mikrokontroller ATMega8535. Berbeda 
dengan perancangan alat otomatisasi penyalaandan mati lampu secara otomatis menggunakan sensor PIR yang berfungsi sebagaifittingekstensi tanpa harus terintegrasi dengan lampu(Bakhtiar \& Suherman n.d.).Sistem cerdas penerangan ini menggunakan pengindraan Infra Merah. Dengan harga Rp.68.750 untuk sensor yang digunakan maka system ini memiliki kelebihan dari biaya bahan baku yang sangat murah. Sensor Infra Merah ini ditempatkan pada jarak $\pm 25 \mathrm{Cm}$ antara pemancar (transmitter) dan penerima (receiver). Tiap Sensor Infra Merah berjarak $20 \mathrm{Cm}$. Penempatan tersebut dengan maksud agar satu sama lain tidak dapat mendeteksi sumber pancaran infra merah dari sensor sekitarnya.

Sistem cerdas ini dapat mengurangi beban daya listrik dikarenakan kondisi seri-paralel disaat lampu menyala.Pada rangkaian seri maka besar arus listrik sama besar, tetapi besar tegangannya berbeda tergantung besar hambatan pada rangkaian. Sedangkan pada rangkaian paralel maka besar tegangan adalah sama untuk setiap hambatan yang terpasang, tetapi arusnya berbeda tergantung besar hambatan terpasang. Selain sebagai materi modul aplikatif kolaborasibanyak mata kuliah di Teknik Elektromedik, berbahan baku sensor yang sangat murah serta dapat dijadikan bahan praktikum atau bahan ajar dari banyak mata kuliah dasar di Jurusan Teknik Elektromedik(Yosi Abdian Tindaon 2012).

Kajian Pustaka

Pada dasarnya system cerdas ini juga telah masuk ke dalam kategori EcoGreen, yang mana system ini mengedepankan prinsip hemat energy dalam aktivasinya. Sistem ini berbahan baku yang mudah didapat, dimana system ini hanya membutuhkan system minimum AVR ATMega8535 dan perangkat Infra Merah dalam transmisi dan penerima sebagai sensornya. Berikut adalah blok modul yang digunakan beserta sumber tegangan masukannya.

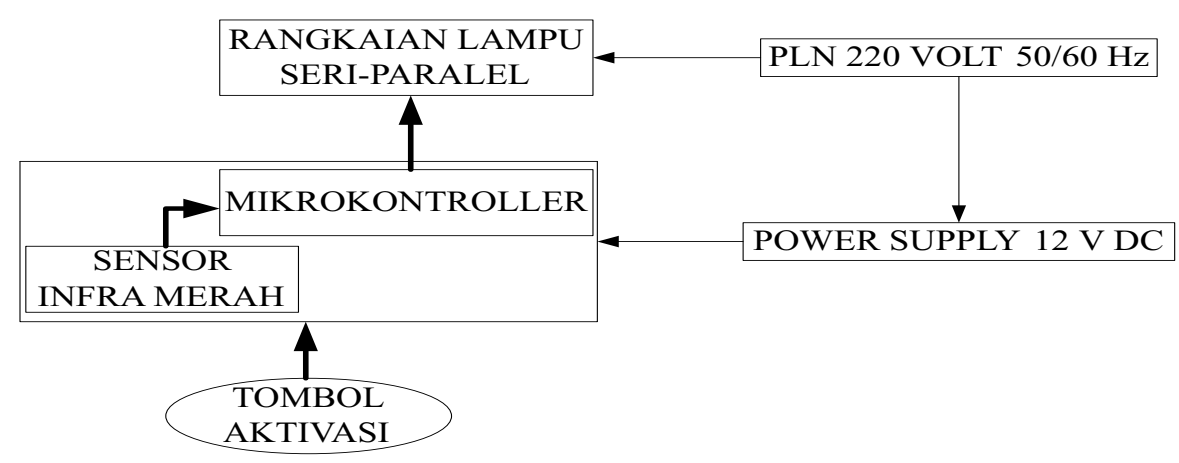

Gambar 1 Bagan Alur Rangkaian Perangkat Sistem Cerdas 
Dari blok modul tersebut dapat dilihat bahwa aktivasi dan deaktivasi keseluruhan system menggunakan suatu tombol (saklar tunggal). Aktivasi pertama kali akan mengaktifkan system kontrolnya. System control utama adalah Mikrokontroller ATMega8535 dengan sensor Infra Merah sebagai sumber masukannya. Keluaran dari system control adalah kondisi pencahayaan rangkaian lampu yakni berupa hubung seri (redup) ataukah dalam hubung parallel (terang).

Mikrokontroler ATMega8535. adalah perangkat yang mengerjakaninstruksi-instruksi yang diberikan kepadanya. Artinya, bagian terpenting dan utamadari suatu sistem terkomputerisasi adalah program itu sendiri yang dibuat olehseorang programmer. Program ini menginstruksikan mikrokontroller untuk melakukanjalinan yang panjang dari aksiaksi sederhana untuk melakukan tugas yang lebihkompleks yang diinginkan oleh programmer.Rangkaian ini menggunakan mikrokontroler

ATMega8535yangmengatur keseluruhan sistem agar dapat bekerja.AVR AT Mega8535 adalah mikrokontroler RISC (Reduce Instruction SetCompute) 8 bit berdasarkan arsitektur Harvard yang dibuat oleh Atmel pada tahun1996. AVR mempunyai kepanjangan Advance Versatile Risc atau Alf dan Vegard'sRisc Processor(Atmel 2006).

Sensor Infra Merah merupakan modul pengirim dan penerima data melalui gelombanginfra merah.Modul ini dapat digunaan sebagai pemancar untuk transmisi data nirkabel dalam aplikasi seperti robotic, system pengamanan, datalogger, absensi, dsb.Nilai dimensi sensor adalah 7.3 Cm (P) x 4.1 Cm (L) x $1.5(\mathrm{~T})$ untuk transmitter dan $3,4 \mathrm{~cm}(\mathrm{P}) \mathrm{x}$ $2,5 \mathrm{~cm}(\mathrm{~L}) \times 1,4 \mathrm{~cm}(\mathrm{~T})$ untuk receiver. Sensor Infra Merah ini juga memiliki fitur Tegangan kerja $+5 \mathrm{~V}$ DC, Frekuensi Carrier $38 \mathrm{KHz}$ (juga untuk penerima dan dapat ditempatkan menggunakan resistor variable), Panjang Gelombang $940 \mathrm{~nm}$ (Puncak), Jarak Maksimmum $16 \mathrm{M}$ (Teruji pada sudut $0^{\circ}$ ) dan $35 \mathrm{M}$ (sesuai Datasheet), Memiliki Input yang kompatibel dengan level tegangan TTL, CMOS dan RS-232, Sudut penerimaan $+45^{\circ}$, Terdapat 2 mode output: NonInverting dan Inverting, Kompatibel penuh dengan DT-51 minimum system Ver 3.0, DT-51PetraFuz, DT-Basic Series, DT-51 Low Cost series, DT-AVR Low Cost series dan system control lain(Depok Instrument 2017)(Depok Instrumen 2017).Berikut adalah gambar Sensor Infra Merah yang digunakan. 


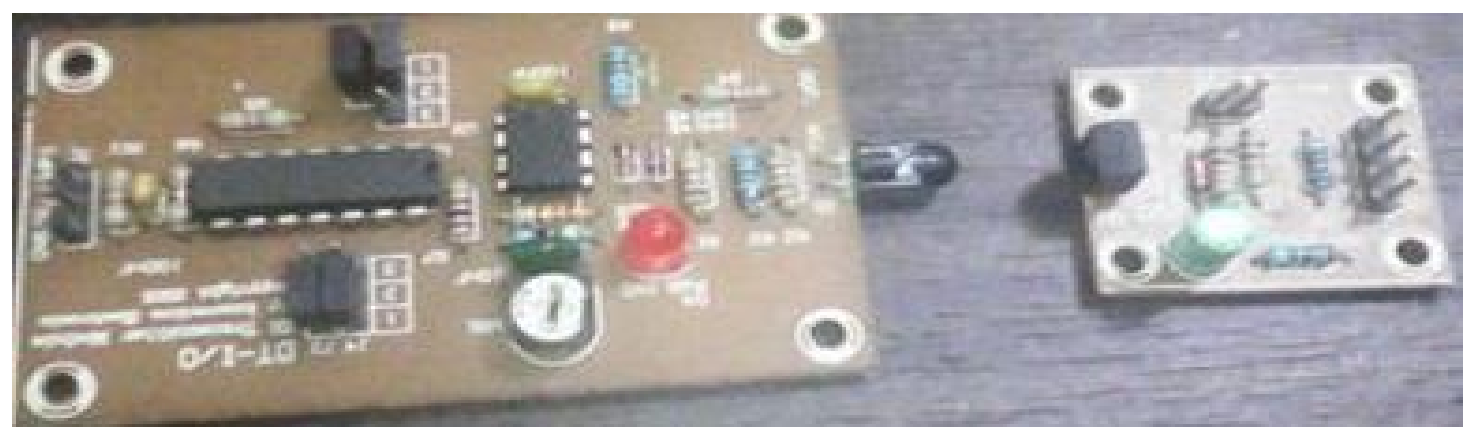

Gambar 2 Sensor Pemancar Infra merah (kiri) dan Sensor Penerima Infra Merah (kanan)

Program

pengembangan

mikrokontroler AVR buatan ATMEL

menggunakan software AVR STUDIO dan

CodeVision AVR. CodeVision AVR

memilki fasilitas terminal, yaitu untuk melakukan komunikasi serial dengan mikrokontroler yang sudah diprogram. Proses download program ke IC mikrokontroler AVR dapat menggunakan sistem download secara In-System Programming (ISP). ISP Flash On-chip mengijinkanmemori program untuk diprogram ulang dalam sistem menggunakan hubungan serial SPI. Mikrokontroler AVR menggunakan bahasa $\mathrm{C}$ dalam penulisan programnya, sehingga dapat memudahkan dan mempersingkat instruksi - intruksi yang digunakan dalam bahasa assembly. Dalam pembuatan program yang menggunakan fungsi atau aritmatika, Bahasa C menawarkan kemudahan dengan menyediakan fungsi - fungsi khusus, seperti: pembuatan konstanta, operator aritmatika, operatot logika, operator bitwise dan operator Assigment. Selain itu, bahasa C menyediakan Program kontrol seperti: Percabangan (if dan if...else), Percabangan switch, Looping (for, while dan do...while), Array, serta fungsi fungsi lainnya.Preprocessor digunakan untuk memasukkan (include) text dari file lain, mendefinisikan macro yang dapat mengurangi beban kerja pemrograman dan meningkatkan legability source code (mudah dibaca)(Prasimax 2003)(Prasimax 2010). Adapun bentuk kerangka teori secara keseluruhan dari system cerdas dapat digambarkan pada kerangka teori di bawah ini. 


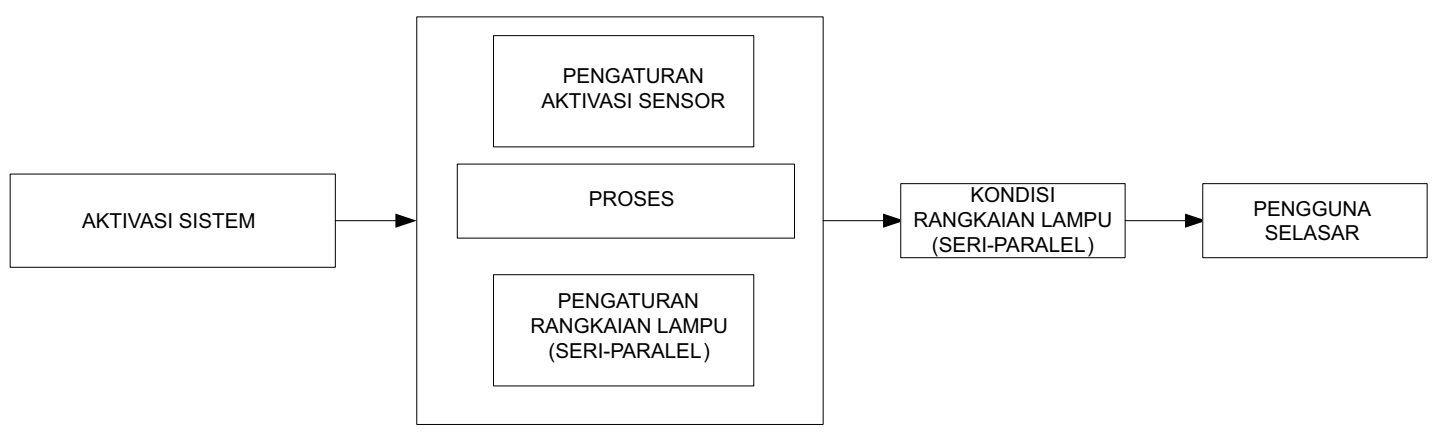

Gambar 3Diagram Alur Kerangka Teori

Rangkaian lampu seri-paralel dan rangkaian lampu parallel.Berikut merupakan rangkaian lampu yang adalah gambar deskripsi dari rangkaian mengintegrasikan rangkaian lampu seri lampu Seri-Paralel yang digunakan.

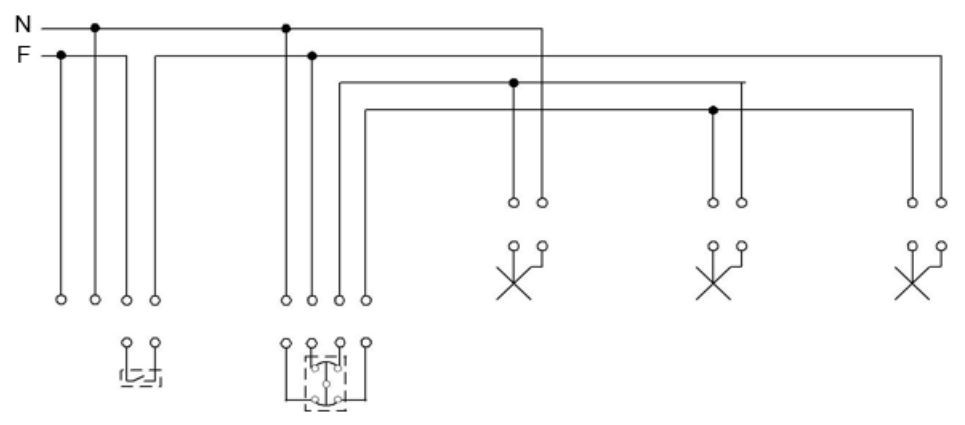

Gambar 4Pengawatan Instalasi Lampu Listrik Seri-Paralel

Pola rangkaian lampu ini dapat memberikan pola rangkaian seri dan rangkaian parallel sekaligus dengan berbantuan saklar dua kutub.Ketika saklar dua kutub yang digunakan dalam posisi terputusmaka rangkaian lampu yang terhubung dalam bentuk seri.Dalam kondisi rangkaian ini, menyalanya lampu dalam keadaan redup.Ketika saklar dua kutub yang digunakan dalam posisi terhubung maka rangkaian lampu yang terhubung dalam bentuk paralel.Dalam kondisi rangkaian ini, menyalanya lampu dalam keadaan terang sesuai dengan nilai dayanya.
Pada rangkaian lampu Seri-Paralel diotomatisasikan oleh Magnetic Contactor (MC).MC ini berfungsi menggantikan saklar dua kutub. MC dapat dikontrol dengan cara mengendalikan aliran arus yang melalui terminal A1 dan A2 pada MC tersebut. Pengendali utama adalah kumparan magnetnya.Terminal-terminal (T1 hingga T3) bekerja layaknya suatu saklar yang bergantung pada ada atau tidaknya arus listrik pada kumparan magnetnya.Terminal-terminal tersebut merupakan saklar NO (Normally Open) yang berupa kondisi awalnya terbuka/terputus.Untuk mengendalikan ada 
atau tidaknya arus pada kumparan diperlukan adanya pengaturan dari mikrokontroller.

Relay Modul merupakan perantara yang menerapkan sifat magnetic dengan kondisi pemantik yang berasal dari Mikrokontroller. Nilai tegangan pemantik adalah 5 Volt DC dan nilai tegangan saluran yang dikoneksikannya adalah 110 Volt AC hingga 380 Volt AC. Beruikut adalah struktur dasar dari sebuah relay dengan kondisi diberikan tegangan 5 Volt DC dan mengendalikan aliran listrik bertegangan 220 Volt AC.

Tujuan

Tujuan Umum penelitian ini ialah melakukan uji coba modul pemodelan system cerdas dengan mengintegrasikan rangkaian lampu seri - parallel dan sensor infra merah sebagai pendeteksi objek bergerak tunggal.

Sedangkan Tujuan khususnya meliputi melakukan perancangan Blok diagram modul system cerdas penerangan, melakukan pembuatan hardware modul system cerdas penerangan yang menggunakan sensor Infra Merah seharga Rp. 68.750,-, melakukan perancangan dan pembuatan software pada modul system cerdas penerangan, melakukan uji fungsi hardware dan software system cerdas penerangan, melakukan uji fungsi keseluruhan pada system cerdas penerangan dan melakukan pendataan dan analisis hipotesa efisiensi daya listrik lampu penerangan hingga $60 \%$ yakni berdaya 25 Watt disaat terang (paralel) dan berdaya 9.80 Watt disaat redup (seri).

\section{METODE}

Penelitian ini merupakan penelitian experimental yang bertujuan untuk menghasilkan system cerdas.Rancang bangunyang digunakan dalam penelitian ini memiliki langkah-langkah yang digambarkan oleh flowchart seperti dibawah ini 


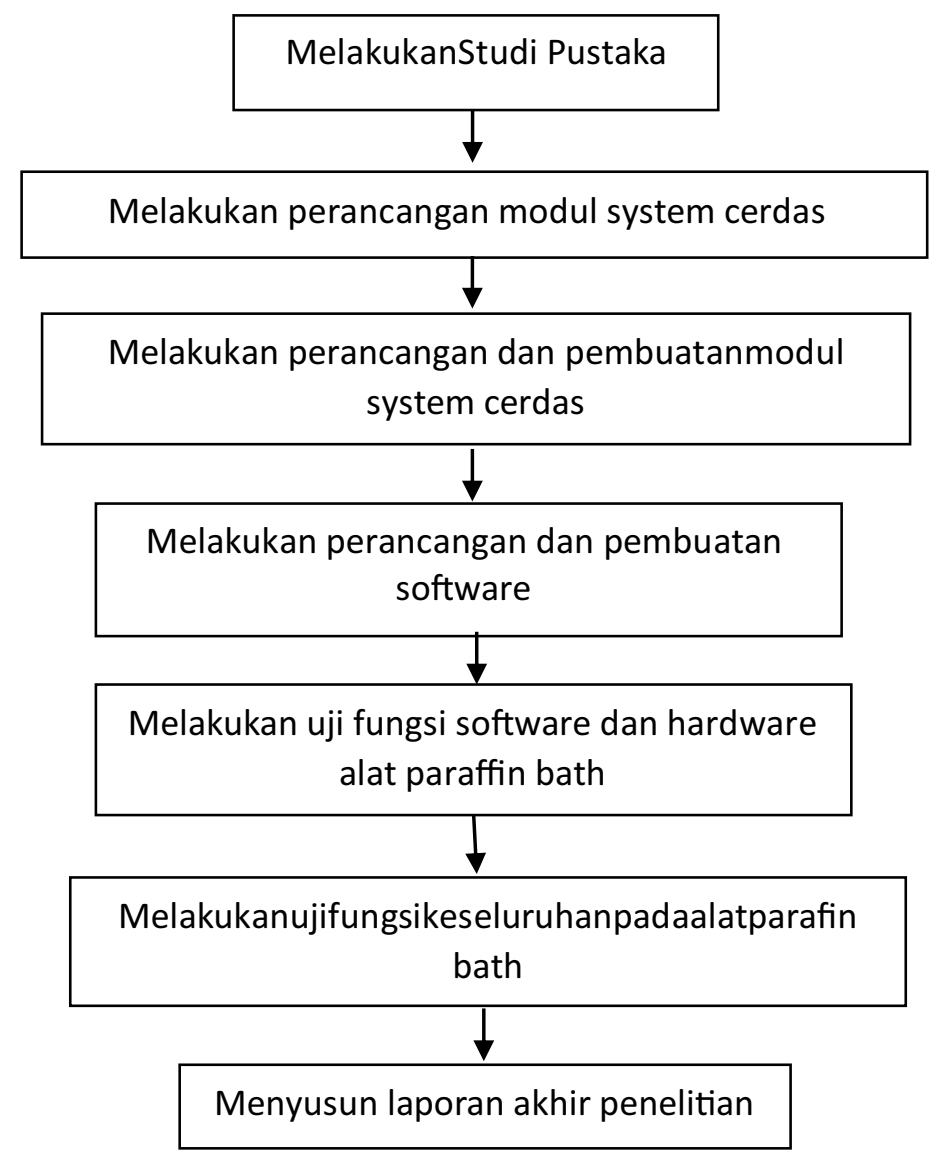

Gambar 5Diagram Alur Rancangan Penelitian

Tahapan penelitian yang digunakan dimulai dari studi pustaka.Tahap ini dilaksanakan dengan mencari dan mempelajari buku-buku dan sumbersumber literatur sebagai kajian-kajian teori yang menunjang dalam pembuatan penelitian. Metode studi literatur merupakan dasar dari pembuatan penelitian ini.

Tahapan berikutnya yakni perencanaan pembuatan alat.Pada tahap ini penulis melakukan perencanaan sekaligus perancangan mengenai komponenkomponen yang dibutuhkan setelah tahapan studi literature terselesaikan. Komponen-komponen yang diinginkan dalam tahap ini yakni Sensor Infra Merah, Sistem minimum mikrokontroller AVR8535, Magnetik Kontaktor, Relay Modul, rumah lampu dan triplek untuk wadah penggabungannya serta jenis kabel untuk penghubung rangkaiannya.

Setelah mengetahui komponenkomponen yang dibutuhkan tersebut, maka hal yang dilakukan penulis ialah mencari dan mengumpulkan komponen-komponen tersebut. Adapun dalam tahap ini dilakukan pengklasifikasian komponen. Seluruh kompunen tersebut dibagi dalam tiga klasifikasi, yakni input, prosessor dan output.Blok masukan meliputi sistem sensor, dalam hal ini ialah sensor Infra 
Merah. Sensor Infra merah ini digunakan karena harganya yang murah, yakni seharga Rp. 68.750,-. Selain harganya yang murah, pemilihan jenis sensor ini adalah untuk membedakan pengaturan otomatis pintu menggunakan yang menggunakan sensor PIR (passive InfraRed)(Sigit n.d.). Blok prosessor hanya berupa mikrokontroller AVR Atmega8535. Blok keluaran yakni rangkaian lampu Seri-Paralel yang diakomodir oleh Relay modul.
Perancangan desain juga meliputi perancangan sistem melalui diagram algoritma (flowchart) sebagai acuan untuk langkah-langkah berikutnya. Diagram algoritma ini merupakan representasi utama dari sistem secara keseluruhan. Pengintegrasian semua sistem dapat mengacu pada diagram algoritma ini. Langkah-langkah keadaan yang terdapat dan terjadi dalam sistem dapat dipahami melalui diagram algoritma ini.

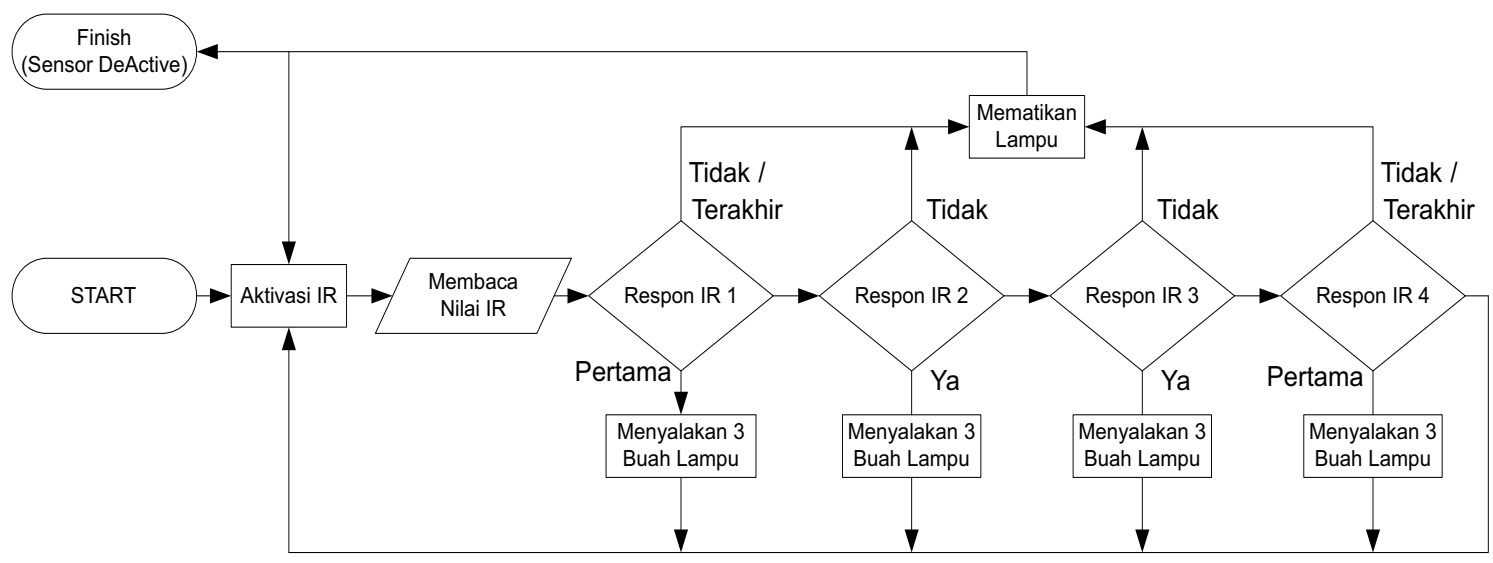

Gambar 6Blok Diagram Alur Kinerja Sistem

Tahapan pembuatan alat diawali dengan melakukan pembuatan purwarupa (Prototype). Pembuatan Prototype tersebut bertujuan untuk memastikan kinerja sistem cerdas dalam lingkum dan lingkungan yang kecil. Langkah berikut setelah pembuatan prototype adalah pemasangan sistem cerdas secara real yang disimulasikan pada selasar kelas lantai dua
Jurusan Teknik Elektromedik Poltekkes Jakarta II . Untuk tahapan ini, penelitian mengalami kendala lokasi yakni selasar tersebut, mulai bulan Agustus, telah beralih fungsi sebagai penampungan lemari dari seluruh ruangan yang dibongkar. Untuk mengatasi hal tersebut, maka penelitian ini hanya dibatasi hingga prototype saja. 


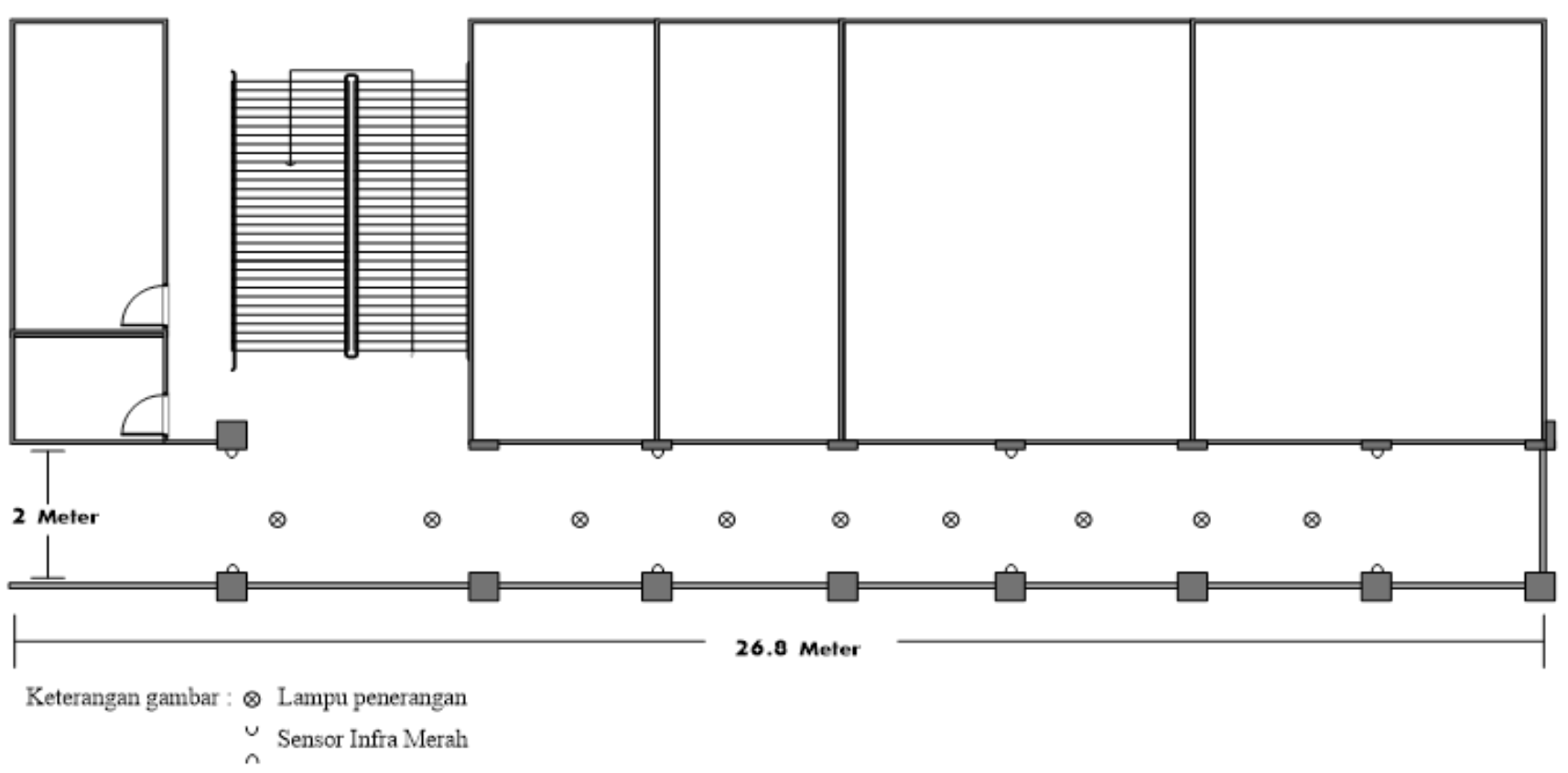

Gambar 7 Ilustrasi Pemasangan Sensor Infra Merah dan Kelompok Lampu Pada Selasar Rumah Sakit Menggunakan Selasar Jurusan Teknik Elektromedik Lantai dua

Pada tahapan pembuatan program (Software) diawali dengan menentukan pin-pin masukan dan keluaran. Tahap berikutnya yakni membuat alur proses atas sinyal informasi yang diberikan dari masukan. Sumber masukan yang berasal dari empat buah sensor Infra merah harus dapat bekerja sesuai dengan diagram alur yang telah dibuat pada perancangan. Untuk masukan dari ke empat sensor tersebut, diposisikan pada PORT A (Transmitter) dan PORT D (receiver). Pemancar dari sensor tersebut dikondisikan untuk selalu aktif dikarenakan penentu objek bergeraknya adalah pada penerimanya. Pengaktifannya dilakukan dengan memberikan kondisi active low pada mikrokontroller. Pada bagian Penerima, sebagai bagian pendeteksi objek bergeraknya, mikrokontroller dikondisikan untuk berkondisi high saat tidak mendeteksi objek bergerak dan berkondisi low saat mendeteksi adanya objek bergerak (misal: if(PIND.2==0)). Kondisi gabungan dari seluruh sensor dilakukan dengan menggunakan perintah dan (\&\&). Keluran dari sistem ada pada Port C. PC.1 adalah keluaran untuk relai 1, PC. 2 untuk relai 2 dan PC.3 untuk relai 3. Kondisi sinyal yang ada pada masing masing pin, juga direpresentasikan oleh menyalanya LED pada masing masing pin yang bereaksi.

Pada tahap berikutnya, dilakukan pengujian alat. Pada tahap ini dilakukan pengujian dari fungsi kerja alat dan membandingkan antara hasil pengukuran dengan teori yang telah ada. Membandingkan hasil kerja alat yang dibuat dengan alat yang ada. Adapun 
langkah-langkah yang dibuat adalah sebagai berikut:

a. Pengujian Masing-Masing Komponen

Setelah memperoleh komponen-komponen yang dibutuhkan, tahap selanjutnya yakni melakukan penyusunan rangkaian yang telah ditentukan dan menguji berfungsi atau tidaknya suatu komponen tersebut.

- Pengujian Sensor Infra Merah dan Sistem Minimum AVR 8535

Pengujian dilakukan hanya pada sensor menggunakan program sederhana yang keluarannya ditampilkan pada LED di Sistem Minimum AVR8535. Pengujian ini dikarenakan komponen ini adalah komponen yang utama untuk sinyal masukan.

- Pengujian Rangkaian Lampu Seri Paralel

Pengujian pada tahapan ini adalah melakukan peangkaian seri-paralel pada tiga buah rangkaian lampu.Pengujiannya hanya pada kondisi redup (seri) dan terang (parallel) nya saja disaat kondisi saklar dua kutubnya dioperasikan.Sejatinya, rangkaian lampu seri-paralel ini menggunakan saklar dua kutub namun untuk otomatisasi, system saklar tersebut digantikan oleh magnetic Contactor.

b. Pengujian rangkaian secara keseluruhan

Pada tahap ini semua komponen dihubungkan.

Dikarenakan bentuk penelitian hanya sampai prototype, maka pengujian tidak dilakukan pada selasar yang direncanakan. Pengujian dilakukan dalam dua tahap, yakni

- Pengujian mikrokontroller dengan empat buah sensor infra merah yang bentuk keluarannya direpresentasikan oleh tampilan LED.

Pada tahap ini Mikrokontroller diprogramkan untuk menerima masukan yang dari empat buah sensor Infrared dengan posisi yang berbeda dengan arah pergerakan yang juga berbeda yakni sensor 1 (sisi kanan) ke sensor 4 (sisi kiri). 


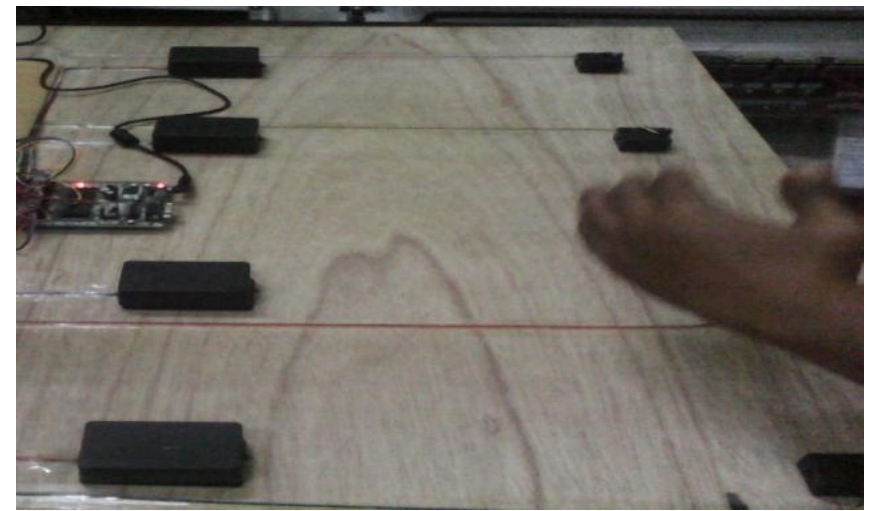

Gambar 8. Pengujian Sistem Keseluruhan Tahap Pertama dengan Empat Buah Sensor IR

Indikator capaian pada tahap ini dapat dilihat pada table uji berikut ini.

Tabel 1 Tabel Hasil Uji Menggunakan Empat Buah Sensor IR dengan pergerakan dari Sensor 1 ke Sensor 4

\begin{tabular}{|l|l|l|l|l|l|l|l|}
\hline $\begin{array}{c}\text { Sensor } \\
\text { Pendeteksi } \\
\text { (Pergerakan } \\
\text { dari sensor 1 }\end{array}$ & \multicolumn{3}{|c|}{ Kondisi Deteksi } & \multicolumn{3}{c|}{ Tampilan Indikator } \\
$\begin{array}{c}\text { menuju ke } \\
\text { sensor 4) }\end{array}$ & \multicolumn{3}{|l|}{} & \multicolumn{3}{c|}{ LED Mikrokontroller } \\
\cline { 5 - 9 } & \multicolumn{2}{|l|}{} & LED & LED & LED \\
PC.0 & PC.1 & PC.2 \\
\hline IR I & Deteksi & Tidak & Tidak & Tidak & On & Off & Off \\
\hline IR 2 & Tidak & Deteksi & Tidak & Tidak & Off & On & Off \\
\hline IR 3 & Tidak & Tidak & Deteksi & Tidak & Off & Off & On \\
\hline
\end{tabular}

Tabel 2 Tabel Hasil Uji Menggunakan Empat Buah Sensor IR dengan pergerakan dari Sensor 4 ke Sensor 1

\begin{tabular}{|c|c|c|c|c|c|c|c|}
\hline \multirow{2}{*}{$\begin{array}{c}\text { Sensor } \\
\text { Pendeteksi } \\
\text { (Pergerakan } \\
\text { dari sensor } 4 \\
\text { menuju ke } \\
\text { sensor 1) }\end{array}$} & \multirow{2}{*}{\multicolumn{4}{|c|}{ Kondisi Deteksi }} & \multicolumn{3}{|c|}{$\begin{array}{l}\text { Tampilan Indikator } \\
\text { LED Mikrokontroller }\end{array}$} \\
\hline & & & & & & LED & LED \\
\hline IR I & Tidak & Tidak & Tidak & Deteksi. & Off & Off & Off \\
\hline IR 2 & Tidak & Tidak & Deteksi & Tidak & On & Off & Off \\
\hline IR 3 & Tidak & Deteksi & Tidak & Tidak & Off & On & Off \\
\hline IR 4 & Deteksi & Tidak & Tidak & Tidak & Off & Off & On \\
\hline
\end{tabular}

Hasil tahapan ini menunjukan bahwa kinerja dari rancangan telah sesuai dengan yang direncanakan.

- Pengujian mikrokontroller dengan empat buah sensor infra merah yang bentuk keluarannya direpresentasikan oleh tampilan
LED. Pada tahap ini modul mikrokontroller dan blok rangkaian lampu Seri-Paralel digabungkan. Penggabungan tersebut menggunakan Relay modul. Disaat Rangkaian lampu belum terhubung ke sumber listrik, Relay modul 
masih bekerja sesuai dengan indicator reaksinya (sesuai rancangan awal). Permasalahan terjadi disaat Rangkaian lampu tersebut telah dihubungkan dengan sumber tegangan. Terjadi "lompatan" menyalanya lampu (Bouncing) yang tak terkendali. Kondisi tersebut dapat dilihat pada gambar di bawah ini.

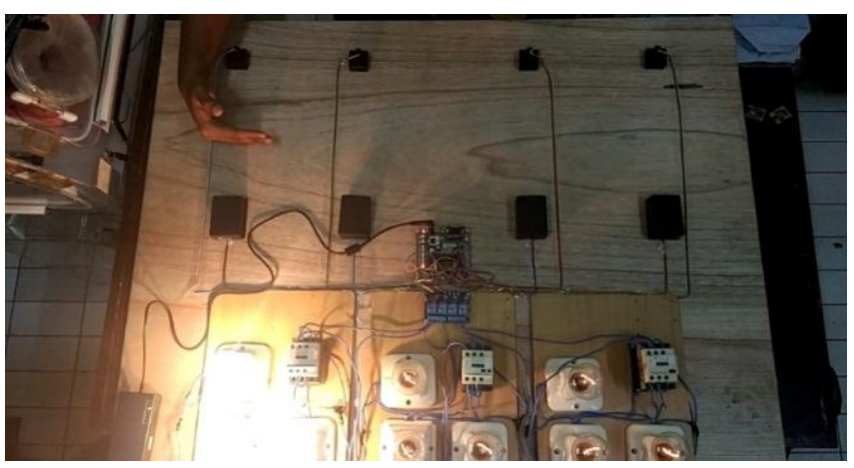

Gambar 9. Kondisi Awal Rangkaian Sebelum Bouncing.

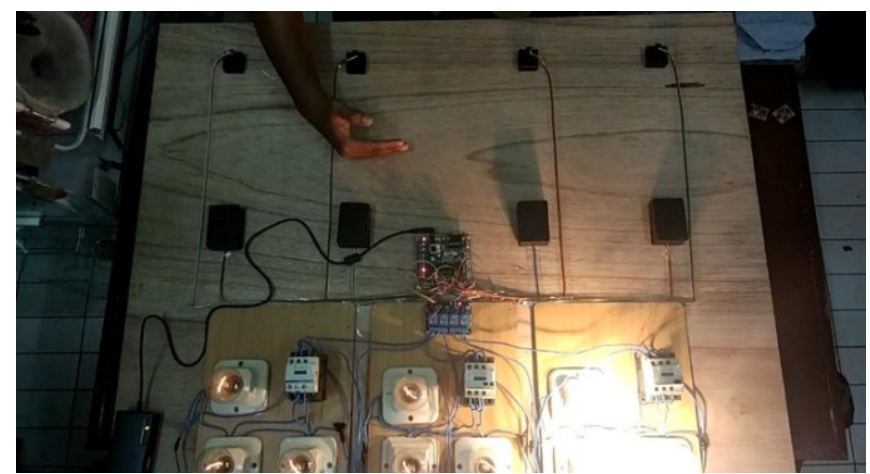

Gambar 10. Kondisi BouncingTerjadi Pada Kelompok Lampu III Disaat Sensor 2 Mendeteksi Objek.

Tahapan terakhir ialah analisis acuan sebelum penelitian dengan hasil data. Pada tahapan ini diperoleh percobaan yang didapatkan, yakni dapat perbandingan antara teori yang dijadikan dilihat pada tabel komparasi di bawah ini.

Tabel 3Komparasi Antara Kondisi Teori Dengan Hasil Percobaan

\begin{tabular}{|c|c|}
\hline Teori Pengaturan Otomatis & Hasil Percobaan \\
\hline $\begin{array}{l}\text { Mikrokontroller menerima rinyal } \\
\text { masukan dari Infra Merah dengan } \\
\text { indikasi keluaran pada LED di sistem } \\
\text { minimumnya }\end{array}$ & Sesuai dengan teorinya. \\
\hline $\begin{array}{l}\text { Mikrokontroller menerima empat } \\
\text { sinyal masukan dari Infra Merah } \\
\text { sekaligus dengan indikasi keluaran } \\
\text { pada LED di sistem minimumnya } \\
\text { dengan pola tertentu }\end{array}$ & Sesuai dengan teorinya. \\
\hline $\begin{array}{l}\text { Relay modul yang dihubungkan } \\
\text { dengan terminal keluaran dari } \\
\text { Mikrokontroller memberikan sinyal }\end{array}$ & Sesuai dengan teorinya. \\
\hline
\end{tabular}




\begin{tabular}{|l|l|}
\hline $\begin{array}{l}\text { kondisi seperti bentuk sinyal keluaran } \\
\text { dari mikrokontroller }\end{array}$ & \\
\hline $\begin{array}{l}\text { Rangkaian Lampu menyala ke posisi } \\
\text { Paralel (terang) sesuai dengan sinyal } \\
\text { yang ada pada relay modul }\end{array}$ & $\begin{array}{l}\text {.Terjadi lompatan (bouncing) pada } \\
\text { kondisi menyalanya lampu }\end{array}$ \\
\hline $\begin{array}{l}\text { Sistem cerdas bekerja sesuai dengan } \\
\text { rancangan pembuatan tanpa } \\
\text { membutuhkan perangkat luar untuk } \\
\text { menopang kinerjanya. }\end{array}$ & $\begin{array}{l}\text { Mikrokontroller mengalami overheat } \\
\text { dikarenakan beban arus yang } \\
\text { disediakan oleh mikrokotroller tidak } \\
\text { mampu menyediakan kebutuhan arus } \\
\text { komponen yang terintegrasi padanya. }\end{array}$ \\
\hline $\begin{array}{l}\text { Kondisi Daya lampu pada saat Seri } \\
\text { (redup) berkurang hingga 60\% menjadi } \\
\text { senilai 10 watt dari daya yang tertera } \\
\text { pada lampu. Kondisi daya menjadi 10 } \\
\text { Watt berdampak pada efisiensi biaya } \\
\text { penerangan lampu. }\end{array}$ \\
\hline
\end{tabular}

Waktu dan Tempat Penelitian ini direncanakan menggunakan selasar kelas jurusan Teknik Elektromedik lantai 2. Rencana tersebut diurungkan karena lokasi tersebut digunakan untuk penampungan lemari buku dari ruangan-ruangan yang dibongkar. Akibat tidak bisa menggunakan selasar tersebut, maka penelitian ini hanya sampai pada tahapan pembuatan purwarupa (prototype) saja. Proses pembuatan perangkat kelas dilakukan di Laboratorium Mikrokontroller dalam jangka waktu lima bulan (Mei s.d September 2016). Adapun pengujian purwarupa dilakukan di ruang workshop Jurusan Teknik Elektromedik dalam jangka waktu satu bulan.

\section{HASIL DAN PEMBAHASAN}

Hasil penelitian ini dilakukan dengan mengatur tiga buah kelompok lampu dengan urutan menyala yang berbeda yang mengacu pada empat buah sensor Infra Merah.Beda urutan penyalahan lampu tersebut bergantung pada awal sensor Infra Merah yang pertama kali menyala.Berikut ini adalah hasil penelitian yang telah didata. 


\section{- Kondisi Pergerakan Yang Berasal dari Sensor IR 1 ke arah sensor IR 4}

Tabel 4 Kondisi Rangkaian Lampu Disaat Sensor IR 1 Mendeteksi Objek

\begin{tabular}{|c|c|c|c|c|c|c|}
\hline \multirow{3}{*}{$\begin{array}{c}\text { Sensor } \\
\text { Infra Merah } \\
\text { Pendeteksi }\end{array}$} & \multicolumn{6}{|c|}{ Kondisi Lampu Berdasarkan kelompok lampu } \\
\hline & \multicolumn{3}{|c|}{ Kelompok Lampu I } & \multicolumn{3}{|c|}{ Daya Lampu ( Watt ) } \\
\hline & $\begin{array}{c}\text { Pola } \\
\text { rangkaian }\end{array}$ & Keterangan & $\begin{array}{l}\text { Daya } \\
\text { (W) }\end{array}$ & $\begin{array}{l}\text { Lampu } \\
\text { I }\end{array}$ & $\begin{array}{l}\text { Lampu } \\
\text { II }\end{array}$ & $\begin{array}{l}\text { Lampu } \\
\text { III }\end{array}$ \\
\hline $\begin{array}{l}\text { IR I terdeteksi } \\
\text { IR II tak }\end{array}$ & Paralel & Terang & 75 & 25 & 25 & 25 \\
\hline $\begin{array}{l}\text { mendeteksi } \\
\text { IR III tak }\end{array}$ & Seri & Redup & 30 & 10 & 10 & 10 \\
\hline $\begin{array}{l}\text { mendeteksi } \\
\text { IR IV tak }\end{array}$ & Seri & Redup & 30 & 10 & 10 & 10 \\
\hline mendeteksi & Seri & Redup & 30 & 10 & 10 & 10 \\
\hline
\end{tabular}

Pada kondisi ini, hanya kelompok lampu I saja yang akan menyala terang dengan jumlah daya total sebesar $100 \%$. Kondisi ini hanya terjadi disaat sensor IR I yang mendeteksi adanya objek. Total daya untuk kelompok lainnya turun sebesar $60 \%$ dari kondisi 25 Watt menjadi 10 Watt.

Tabel 5 Kondisi Rangkaian Lampu Disaat Sensor IR 2 Mendeteksi Objek

\begin{tabular}{|c|c|c|c|c|c|c|}
\hline \multirow{3}{*}{$\begin{array}{c}\text { Sensor } \\
\text { Infra Merah } \\
\text { Pendeteksi }\end{array}$} & \multicolumn{6}{|c|}{ Kondisi Lampu Berdasarkan kelompok lampu } \\
\hline & \multicolumn{3}{|c|}{ Kelompok Lampu II } & \multicolumn{3}{|c|}{ Daya Lampu ( Watt ) } \\
\hline & $\begin{array}{c}\text { Pola } \\
\text { rangkaian }\end{array}$ & Keterangan & $\begin{array}{l}\text { Daya } \\
\text { (W) }\end{array}$ & $\begin{array}{c}\text { Lampu } \\
\text { I }\end{array}$ & $\begin{array}{l}\text { Lampu } \\
\text { II }\end{array}$ & $\begin{array}{l}\text { Lampu } \\
\text { III }\end{array}$ \\
\hline $\begin{array}{c}\text { IR I tak } \\
\text { mendeteksi } \\
\text { IR II }\end{array}$ & Seri & Redup & 30 & 10 & 10 & 10 \\
\hline $\begin{array}{l}\text { terdeteksi } \\
\text { IR III tak }\end{array}$ & Paralel & Terang & 75 & 25 & 25 & 25 \\
\hline $\begin{array}{l}\text { mendeteksi } \\
\text { IR IV tak }\end{array}$ & Seri & Redup & 30 & 10 & 10 & 10 \\
\hline mendeteksi & Seri & Redup & 30 & 10 & 10 & 10 \\
\hline
\end{tabular}

Pada kondisi ini, hanya kelompok lampu II saja yang akan menyala terang dengan jumlah daya total sebesar $100 \%$. Kondisi ini hanya terjadi disaat sensor IR II yang mendeteksi adanya objek. Total daya untuk kelompok lainnya turun sebesar 60\%dari kondisi 25 Watt menjadi 10 Watt. 
Tabel 6 Kondisi Rangkaian Lampu Disaat Sensor IR 3 Mendeteksi Objek

\begin{tabular}{|c|c|c|c|c|c|c|}
\hline \multirow{3}{*}{$\begin{array}{c}\text { Sensor } \\
\text { Infra Merah } \\
\text { Pendeteksi }\end{array}$} & \multicolumn{6}{|c|}{ Kondisi Lampu Berdasarkan kelompok lampu } \\
\hline & \multicolumn{3}{|c|}{ Kelompok Lampu II } & \multicolumn{3}{|c|}{ Daya Lampu ( Watt ) } \\
\hline & $\begin{array}{c}\text { Pola } \\
\text { rangkaian }\end{array}$ & Keterangan & $\begin{array}{l}\text { Daya } \\
\text { (W) }\end{array}$ & $\begin{array}{l}\text { Lampu } \\
\text { I }\end{array}$ & $\begin{array}{l}\text { Lampu } \\
\text { II }\end{array}$ & $\begin{array}{l}\text { Lampu } \\
\text { III }\end{array}$ \\
\hline $\begin{array}{c}\text { IR I tak } \\
\text { mendeteksi }\end{array}$ & Seri & Redup & 30 & 10 & 10 & 10 \\
\hline $\begin{array}{l}\text { IR II terdeteksi } \\
\text { IR III tak }\end{array}$ & Paralel & Terang & 75 & 25 & 25 & 25 \\
\hline $\begin{array}{l}\text { mendeteksi } \\
\text { IR IV tak }\end{array}$ & Seri & Redup & 30 & 10 & 10 & 10 \\
\hline mendeteksi & Seri & Redup & 30 & 10 & 10 & 10 \\
\hline
\end{tabular}

Pada kondisi ini, hanya kelompok lampu III saja yang akan menyala terang dengan jumlah daya total sebesar $100 \%$. Kondisi ini hanya terjadi disaat sensor IR III yang mendeteksi adanya objek. Total daya untuk kelompok lainnya turun sebesar $60 \%$ dari kondisi 25 Watt menjadi 10 Watt.

Tabel 7 Kondisi Rangkaian Lampu Disaat Sensor IR 4 Mendeteksi Objek

\begin{tabular}{|c|c|c|c|c|c|c|}
\hline \multirow{3}{*}{$\begin{array}{c}\text { Sensor } \\
\text { Infra Merah } \\
\text { Pendeteksi }\end{array}$} & \multicolumn{6}{|c|}{ Kondisi Lampu Berdasarkan kelompok lampu } \\
\hline & \multicolumn{3}{|c|}{ Kelompok Lampu III } & \multicolumn{3}{|c|}{ Dava Lampu (Watt) } \\
\hline & $\begin{array}{c}\text { Pola } \\
\text { rangkaian }\end{array}$ & Keterangan & $\begin{array}{l}\text { Daya } \\
\text { (W) }\end{array}$ & $\underset{\text { I }}{\text { Lampu }}$ & $\begin{array}{l}\text { Lampu } \\
\text { II }\end{array}$ & $\begin{array}{l}\text { Lampu } \\
\text { III }\end{array}$ \\
\hline $\begin{array}{c}\text { IR I tak } \\
\text { mendeteksi } \\
\text { IR II tak }\end{array}$ & Seri & Redup & 30 & 10 & 10 & 10 \\
\hline $\begin{array}{c}\text { mendeteksi } \\
\text { IR III tak }\end{array}$ & Seri & Redup & 30 & 10 & 10 & 10 \\
\hline mendeteksi & Seri & Redup & 30 & 10 & 10 & 10 \\
\hline IR IV terdeteksi & Seri & Redup & 30 & 10 & 10 & 10 \\
\hline
\end{tabular}

Pada kondisi ini, seluruh kelompok lampu akan terangkai seri dengan total penurunan daya keseluruhannya adalah 60\%dari kondisi 25 Watt menjadi 10 Watt. 


\section{- Kondisi Pergerakan Yang Berasal dari Sensor IR 4 ke arah sensor IR 1}

Tabel 8 Kondisi Rangkaian Lampu Disaat Sensor IR 4 Mendeteksi Objek

\begin{tabular}{|c|c|c|c|c|c|c|}
\hline \multirow{2}{*}{$\begin{array}{c}\text { Sensor } \\
\text { Infra Merah }\end{array}$ Pendeteksi } & \multicolumn{5}{|c|}{ Kondisi Lampu Berdasarkan kelompok lampu } \\
\cline { 2 - 7 } & Pola rangkaian & Keterangan & Daya (W) & Lampu I & Lampu II & Lampu III \\
\cline { 2 - 7 } & Seri & Redup & 30 & 10 & 10 & 10 \\
\hline IR I tak mendeteksi & Seri & Redup & 30 & 10 & 10 & 10 \\
\hline IR II tak mendeteksi & Seri & Redup & 30 & 10 & 10 & 10 \\
\hline IR III tak mendeteksi & Paralel & Terang & 75 & 25 & 25 & 25 \\
\hline IR IV terdeteksi & &
\end{tabular}

Pada kondisi ini, hanya kelompok lampu III saja yang akan menyala terang dengan jumlah daya total sebesar $100 \%$. Kondisi ini hanya terjadi disaat sensor IR IV yang mendeteksi adanya objek. Total daya untuk kelompok lainnya turun sebesar 60\%dari kondisi 25 Watt menjadi 10 Watt.

Tabel 9 Kondisi Rangkaian Lampu Disaat Sensor IR 3 Mendeteksi Objek

\begin{tabular}{|c|c|c|c|c|c|c|}
\hline \multirow{2}{*}{$\begin{array}{c}\text { Sensor } \\
\text { Infra Merah }\end{array}$ Pendeteksi } & \multicolumn{5}{|c|}{ Kondisi Lampu Berdasarkan kelompok lampu } \\
\cline { 2 - 7 } & Pola rangkaian & Keterangan & Daya (W) & Lampu I & Lampu II & Lampu III \\
\cline { 2 - 7 } & Seri & Redup & 30 & 10 & 10 & 10 \\
\hline IR tak mendeteksi & Seri & Redup & 30 & 10 & 10 & 10 \\
\hline IR tak mendeteksi & Paralel & Terang & 75 & 25 & 25 & 25 \\
\hline IR III terdeteksi & Seri & Redup & 30 & 10 & 10 & 10 \\
\hline IR tak mendeteksi & &
\end{tabular}

Pada kondisi ini, hanya kelompok lampu II saja yang akan menyala terang dengan jumlah daya total sebesar $100 \%$. Kondisi ini hanya terjadi disaat sensor IR III yang mendeteksi adanya objek. Total daya untuk kelompok lainnya turun sebesar 60\%dari kondisi 25 Watt menjadi 10 Watt.

Tabel 10 Kondisi Rangkaian Lampu Disaat Sensor IR 2 Mendeteksi Objek

\begin{tabular}{|c|c|c|c|c|c|c|}
\hline \multirow{2}{*}{$\begin{array}{c}\text { Sensor } \\
\text { Infra Merah }\end{array}$ Pendeteksi } & \multicolumn{5}{|c|}{ Kondisi Lampu Berdasarkan kelompok lampu } \\
\cline { 2 - 7 } & Pola rangkaian & Keterangan & Daya (W) & Lampu I & Lampu II & Lampu III \\
\cline { 2 - 7 } & Seri & Redup & 30 & 10 & 10 & 10 \\
\hline IR I tak mendeteksi & Paralel & Terang & 75 & 25 & 25 & 25 \\
\hline IR II Off & Seri & Redup & 30 & 10 & 10 & 10 \\
\hline IR III tak mendeteksi & Seri & Redup & 30 & 10 & 10 & 10 \\
\hline IR IV tak mendeteksi & &
\end{tabular}

Pada kondisi ini, hanya kelompok lampu I saja yang akan menyala terang dengan jumlah daya total sebesar $100 \%$. Kondisi ini hanya terjadi disaat sensor IR II yang mendeteksi adanya objek. Total daya untuk kelompok lainnya turun sebesar 60\%dari kondisi 25 Watt menjadi 10 Watt.

Tabel 11 Kondisi Rangkaian Lampu Disaat Sensor IR 1 Mendeteksi Objek

\begin{tabular}{|c|c|c|c|c|c|c|}
\hline \multirow{3}{*}{$\begin{array}{c}\text { Sensor } \\
\text { Infra Merah } \\
\text { Pendeteksi }\end{array}$} & \multicolumn{6}{|c|}{ Kondisi Lampu Berdasarkan kelompok lampu } \\
\hline & \multicolumn{3}{|c|}{ Kelompok Lampu III } & \multicolumn{3}{|c|}{ Daya Lampu ( Watt ) } \\
\hline & Pola rangkaian & Keterangan & Daya $(\mathrm{W})$ & Lampu I & Lampu II & Lampu III \\
\hline IR I terdeteksi & Seri & Redup & 30 & 10 & 10 & 10 \\
\hline IR II tak mendeteksi & Seri & Redup & 30 & 10 & 10 & 10 \\
\hline IR III tak mendeteksi & Seri & Redup & 30 & 10 & 10 & 10 \\
\hline IR IV tak mendeteksi & Seri & Redup & 30 & 10 & 10 & 10 \\
\hline
\end{tabular}

Pada kondisi ini, seluruh kelompok lampu akan terangkai seri dengan total penurunan daya keseluruhannya adalah 60\%dari kondisi 25 Watt menjadi 10 Watt. 


\section{SIMPULAN}

Pembuatas system cerdas ini dapat dipermudah dengan terlebih dahulu membuat perancangan Blok diagram. Efisiensi awal dari system cerdas ini adalah pada sensor infra-merah, seharga Rp.68.750,-, yang dapat digunakan sebagai pemberi masukan. Sistem ini mengadopsi system penerangan lampu seri-parallel yang dikontrol oleh mikrokontroller ATMega8535. Integrasi antara program dan hardware telah sesuai dengan blok perancangan system.Uji program dilakukan dengan dua tahap dengan kondisi pertama berhasil (pengujian dengan lampu tidak terhubung ke sumber daya) dan kondisi kedua menghasilkan keadaan bouncing (lompatan) (pengujian dengan lampu terhubung ke sumber daya). Dari hasil pengujian nilai daya listrik, dihasilkan efisiensi biaya listrik sebesar $60 \%$, yakni adanya penurunan beban daya listrik lampu dari 25 watt menjadi 9.80 watt untuk setiap lampunya. Penurunan penggunaan daya listrik ini dapat pula mengurangi biaya pembayaran listrik.

\section{DAFTAR RUJUKAN}

Datasheet ATMega 8535 (L).2006. Atmel. pp.1-112. Available at: http://www.atmel.com/Images/doc25 02.pdf.

Bakhtiar \& Suherman. Realisasi Sistem Switch Lampu Penerangan Ruangan Otomatis Untuk Meningkatkan
Efisiensi Energi Listrik. Arus Elektro Indonesia (eJAEI), pp.23-30. Available at: http://jurnal.unej.ac.id/index.php/EJAEI/article/view/1750.

Pedoman pencahayaan di Rumah Sakit.1992: Departemen Kesehatan RI.

Persyaratan kesehatan lingkungan rumah sakit.2004: Departemen Kesehatan RI

Depok Instrumen. 2017. PRASIMAX MIKRON - DT-I/O Infra Red Transmitter. mikron123.com. Available at: http://www.mikron123.com/index.ph p/Modul-Infrared/DT-I/O-Infra-RedTransmitter/Detailed-productflyer.html [Accessed March 27, 2017].

Depok Instrument. 2017. PRASIMAX MIKRON - DT-I/O Infra Red Receiver. mikron123.com. Available at:

http://www.mikron123.com/index.ph p/Modul-Infrared/DT-I/O-Infra-RedReceiver/Detailed-product-flyer.html [Accessed March 27, 2017].

Gunadarma, U.2002. UNIT II INSTALASI PENERANGAN RUANG PENTAS SATU FASE. In Universitas Gunadarma, pp. 1-7.

Malalina \& Kesumawati, N., 2013. Pengembangan Bahan Ajar Interaktif Berbasis Komputer. Jurnal Pendidikan Matematika, 7(2), pp.5570.

Penghematan Pemakaian Tenaga Listrik.2012:Kementerian ESDM

Park, J., Nunogaki, T. \& Lee, J.-H., 2015. The mechanical structure of mobile module for new self-configurable intelligent environment. 
ROBOMECH Journal, 2(1), p.14. Available at: http://www.robomechjournal.com/co ntent/2/1/14.

Prasimax, 2010. Intermediate of Microcontroller, Depok.

Prasimax, 2003. Microcontroller ATMEL $A V R$, Depok.

Sigit, F.M., Perancangan Proximity Sensor Berbasis Kapasiif Untuk Kontrol Pintu Otomatis. In Jurusan Teknik Elektro, Institut Teknologi Sepuluh Nopember, Surabaya. pp. 1-9.

Yosi Abdian Tindaon, 2012. Bahasa dan Sastra Indonesia: Pengertian Bahan Ajar. Google. Available at: http://yosiabdiantindaon.blogspot.co.i $\mathrm{d} / 2012 / 04 /$ pengertian-bahanajar.html. 
